DOI 10.22455/2619-0311-2018-4-78-82

УДК 8.82 .091

ББК $83.3(2)$

П.С. Глушаков

Павел Федорович Смердяков и другие:

две заметки

P.S. Glushakov

\title{
Pavel Fedorovich Smerdyakov and Others: Two Notes
}

Об авторе: Павел Сергеевич Глушаков, доктор филологических наук, независимый исследователь, Рига (Латвия).

E-mail: glushakovp@mail.ru

Аннотация: Статья состоит из двух частей, каждая из которых исследует историко-типологические характеристики образа Смердякова. В первой заметке высказывается предположение, что образ этого героя романа Достоевского повлиял на структуру образа одного из персонажей Василия Шукшина. Во второй заметке высказана гипотеза о том, что образ Смердякова мог в определенной степени повлиять на некоторые характеристики главного героя романа «Как закалялась сталь» - Павла Корчагина.

Ключевые слова: Достоевский, «Братья Карамазовы», Смердяков, Булгаков, Шукшин, литературная параллель.

Для цитирования: Глушаков П.С. Павел Федорович Смердяков и другие: две заметки // Достоевский и мировая культура. 2018. № 4. С. 78-82. DOI 10.22455/2619-0311-2018-4-78-82

About the author: Pavel S. Glushakov, Doctor of Philology, independent researcher, Riga (Latvia).

E-mail: glushakovp@mail.ru

Abstract: The article consists of two parts, each of which explores the historical and typological characteristics of the image of Smerdyakov. The first note suggests that the image in this hero of Dostoevsky's novel influenced the structure of the image of one of Vasily Shukshin's characters. In the second note, it was hypothesized that the image of Smerdyakov could to some extent influence some characteristics of the main character of the novel "How the Steel Was Tempered" - Pavel Korchagin.

Key words: Dostoyevsky, "The Brothers Karamazov", Smerdyakov, Bulgakov, Shukshin, literary parallel.

For citation: Glushakov P.S. Pavel Fedorovich Smerdyakov and Others: Two Notes // Dostoevsky and World Culture. 2018. No 4. Pp. 78-82. DOI 10.22455/2619-0311-2018-4-78-82 


\section{1. Смердяков - Шариков - Баев}

А.К. Жолковский в своей давней работе обнаружил «еще один классический прототип» булгаковского Шарикова - Смердякова, а также высказал убедительное предположение, что «Шариков в значительной степени «сделан» из Смердякова» [Жолковский 1995: 568].

Можно предложить еще одну гипотезу: образ Смердякова, а также образ Шарикова (соединенные в некотором сложном единстве) были восприняты в рассказе Василия Шукшина «Беседы при ясной луне» (1972).

В шукшинском произведении происходит довольно изощренная сепарация мотивных элементов: на образ по преимуществу идеологический (Смердяков) наслаивается метаморфоза мифосимволического порядка (Шариков). При этом, видимо, мы имеем дело с тем явлением, которое по сути противоположно описанному А. К. Жолковским: здесь не «сделанность», а случайное совпадение мотивов и структурных элементов (тем более, что «Собачье сердце» не было еще при жизни Шукшина опубликовано, и знакомство с этим текстом маловероятно).

Один из героев «Бесед при ясной луне» - Баев - следует идеолого-риторической позиции Смердякова («...умная нация покорила бы весьма глупую-с и присоединила к себе» [Достоевский 1976: XIV, 205]) и Шарикова, ставшего уже к тому времени вновь собакой («Окончательно уверен я, что в моем происхождении нечисто. Тут не без водолаза. Потаскуха была моя бабушка, царство ей небесное, старушке» [Булгаков 1998: 435]). При этом прооперированный Шарик предается своим мечтам в «густую пречистенскую ночь с ее одинокою звездою», что определенно сближает эту мотивную ситуацию с излюбленным шукшинским континуумом: «- Ну!.. - Баев полез опять за пузырьком. - А в кого я такой башковитый? Я вот думаю: мериканцы-то у нас тут тада рылись - искали чего-то в горах... Шут его знает! Они же... это... народишко верткий.

- Дак, а похож-то?

- Ну!.. Похож! Потрись с малых лет возле человека - будешь похож. Собака вон на хозяина и то становится похожая, а человек-то... Шут его знает! Может, и грех на душу беру. Но шибко уж у нас с им... противоположные взгляды. Вот чую сердцем: не крестьянского я замеса. Сроду меня не тянуло пахать или там сеять... ни к какой крестьянской работе. И к вину никогда не манило. - Баев не то что оголтело утверждал, что он не крестьянского рода, а скорей размышлял и сомневался. - Ведь если так-то подумать: куда же это все во мне подевалось? Должен же я 
стремиться землю иметь или там... буянить на праздники. Нет! В огороде своем собственном копаться не люблю! Вот в конторе посиживать это по мне...» [Шукшин 1996: II, 138].

Неразвитая метаморфоза «собака, похожая на хозяина» и конструкции «потрись... возле человека» и «сердцем чую» поддерживают потенциальный зооморфный («собачий») мотивный комплекс рассказа ${ }^{1}$.

Линия Смердякова ${ }^{2}$, заявленная в образе Баева ${ }^{3}$ (который, как и Смердяков в линии с Марьей Кондратьевной, имеет некоторые виды на Марью Селезневу), выражается в том, что шукшинский персонаж, наделенный явственной душевной ущербностью, ненавидит людей («Черт их теперь знает, И знать не хочу... Сброд всякий» [Шукшин 1996: II, 144]), скептически оценивает русскую историю как таковую4, а также в той совершенно необъяснимой детали, которая может стать понятной только при припоминании способа самоубийства Смердякова: «В животе у Баева затревожилось, он скоренько завинтил флакончик с табаком, спрятал его в карман, поднялся.

- Пойду. <...>

А такая была ясность кругом, такая была тишина и ясность, что как-то даже не по себе маленько, если всмотреться и вслушаться. Неспокойно как-то. В груди что-то такое... Как будто подкатит что-то

1 Демонстрируя стойкое презрение к роду человеческому, Баев постоянно использует в своей речи анималистические характеристики, называя знакомых ему людей «козлами» и «кобелями».

2 Можно предположить, что еще одна образная деталь - странная привычка Смердякова к рассматриванию пищи («...сидит за супом, возьмет ложку и ищет-ищет в супе, нагибается, высматривает, почерпнет ложку и подымет на свет») - отозвалась в рассказе «Микроскоп», в том его эпизоде, когда Андрей Ерин, приобретя чаемый прибор, первым делом бросился рассматривать в него воду: «- Ты знаешь, что тебя на каждом шагу окружают микробы? Вот ты зачерпнула кружку воды... Так? - Андрей зачерпнул кружку воды. - Ты думаешь, ты воду пьешь?» Здесь же появляется уже отмеченный мотив: «- Вот они, собаки!.. - прошептал Андрей Ерин. С каким-то жутким восторгом прошептал: - Разгуливают. <...> Ах, собаки!» [Шукшин 1996: I, 396] Конечно, в данном случае это, скорее, экспрессивное словоупотребление, тем не менее, небезынтересно как возможное проявление связного мотивного комплекса.

3 Неочевидна, но не исключена возможность косвенного сопоставления номинации шукшинского персонажа и «отталкивающей» семантики фамилии Смердякова: Баев демонстративно рассказывает историю своего пребывания в больнице, изобилующую обонятельными подробностями: «Калу, - говорят, - девятьсот грамм и поту пузырек» [Шукшин 1996: II, 143].

4 «- Мне счас внучка книжку читает: Александра Невский землю русскую защищал... Написано хорошо, но только я ни одному слову не верю там.

Марья и Петька посмотрели на старика.

- Не верю! - еще раз с силой сказал Баев. - Выдумал... и получил хорошие деньги.

- Как это? - не поняла Марья.

- Наврал, как! Не врут, что ли?» [Шукшин 1996: II, 139] 
горячее к сердцу и снизу и в виски мягко стукнет. И в ушах толчками пошумит кровь. И все, и больше ничего на земле не слышно. И висит на веревке луна» [Шукшин 1996: II, 141].

\section{2. Смердяков - Корчагин}

«-Ах, я усмехнулся совсем другому. Видите, чему я усмехнулся: я недавно прочел один отзыв одного заграничного немца, жившего в России, об нашей теперешней учащейся молодежи: “Покажите вы, - он пишет, русскому школьнику карту звездного неба, о которой он до тех пор не имел никакого понятия, и он завтра же возвратит вам эту карту исправленною”. Никаких знаний и беззаветное самомнение - вот что хотел сказать немец про русского школьника» [Достоевский 1976: XIV, 502].

Обыкновенно эти слова в пересказе Алеши Карамазова служат подтверждением мысли о «загадочной русской душе» и творческих силах в ней сокрытых и вызывают, как минимум, одобрительную реакцию, хотя высказаны они немцем, которого, по замечанию Коли Красоткина, «все-таки... надо душить».

Между тем, кажется, не все так благостно с этой сентенцией. На страницах «Братьев Карамазовых» есть эпизод, который отдаленно напоминает о пресловутых русских мальчиках: «Как-то однажды, всего только на втором иль на третьем уроке, мальчик вдруг усмехнулся.

- Чего ты? - спросил Григорий, грозно выглядывая на него из-под очков.

- Ничего-с. Свет создал Господь Бог в первый день, а солнце, луну и звезды на четвертый день. Откуда же свет-то сиял в первый день?

Григорий остолбенел. Мальчик насмешливо глядел на учителя. Даже было во взгляде его что-то высокомерное. Григорий не выдержал. “А вот откуда!” - крикнул он и неистово ударил ученика по щеке. Мальчик вынес пощечину, не возразив ни слова, но забился опять в угол на несколько дней. Как раз случилось так, что через неделю у него объявилась падучая болезнь в первый раз в жизни, не покидавшая его потом во всю жизнь» [Достоевский 1976: XIV, 114].

Звали этого мальчика Павликом Смердяковым.

Однако на этом, видимо, история пытливых русских мальчиков не кончается. Еще один эпизод связан с именем еще одного Павла, на этот раз Корчагина: «Учитель, сухонький, в черном пиджаке, рассказывал про землю, светила. Павка слушал, разинув рот от удивления, что земля уже существует много миллионов лет и что звезды тоже вроде земли. До того 
был удивлен услышанным, что даже пожелал встать и сказать учителю: “В законе божием не так написано”, но побоялся, как бы не влетело.

По закону божию поп всегда ставил Павке пять. Все тропари, Новый и Ветхий завет знал он назубок: твердо знал, в какой день что произведено богом. Павка решил расспросить отца Василия. На первом же уроке закона, едва поп уселся в кресло, Павка поднял руку и, получив разрешение говорить, встал:

- Батюшка, а почему учитель в старшем классе говорит, что земля миллион лет стоит, а не как в законе божием - пять тыс... - и сразу осел от визгливого крика отца Василия:

- Что ты сказал, мерзавец? Вот ты как учишь слово божие!

Не успел Павка и пикнуть, как поп схватил его за оба уха и начал долбить головой об стенку. Через минуту, избитого и перепуганного, его выбросили в коридор» [Островский 1982: 6].

Естественно, что мальчик «возненавидел с тех пор попа... всем своим существом. Ненавидел и боялся. Никому не прощал он своих маленьких обид: не забывал и попу незаслуженную порку, озлобился, затаился» [Островский 1982: 6].

Эти затаенные мальчики и определили судьбу России в веке двадцатом.

\section{Список литературы}

1. Булгаков М. Сочинения в трех томах. Т. 1. СПб.: Кристалл, 1998. 688 с.

2. Достоевский Ф.М. Полное собрание сочинений: в 30 т. Т. 14. Л.: Наука, 1976. 514 с.

3. Жолковский А. К. О Смердякове (К проблеме «Булгаков и Достоевский») // Лотмановский сборник. Вып. 1. М.: ИЦ-Гарант, 1995. С. 568-580.

4. Островский Н. Как закалялась сталь. М.: Правда, 1982. 304 с.

5. Шукшин В. М. Собрание сочинений в 5 т. Т. 2. М.: Литературное наследие, 1996.566 с.

\section{References}

1. Bulgakov M. Sochinenija v trekh tomakh [Works in 3 vols.]. Vol. 1. St. Petersburg, Kristall Publ., 1998. 688 p.

2. Dostoyevsky F. Polnoje sobraniye sochineniy v 30 t. [Collected Works in 30 vols.]. Vol. 14. Lenigrad, Nauka Publ., 514 p. (In Russ.)

3.Zholkovsky A. O Smerdyakove (K probleme "Bulgakovi Dostoyevsky") [About Smerdyakov (To the problem "Bulgakov and Dostoevsky")]. Lotmanovkiy sbornik [Collection of Works in Memory of Lotman]. Moscow, IC-Garant Publ., 1995. Vol. I. Pp. 568-580. 1995. (In Russ.)

4. Ostrovskij N. Kak zakalyalas' stal' [How the Steel Was Tempered]. Moscow, Pravda Publ., 1982. 304 p. (In Russ.)

5. Shukshin V. Sobranije sochineniy v 5 t. [Collected Works in 5 vols.]. Vol. 2. Moscow, Literaturnoye naslediye Publ., 1996. 566 p. (In Russ.) 